\title{
COASTAL CAVES IN BAHAMIAN EOLIAN CALCARENITES: DIFFERENTIATING BETWEEN SEA CAVES AND FLANK MARGIN CAVES USING QUANTITATIVE MORPHOLOGY
}

\author{
Willapa J. Waterstrat, John E. Mylroie, Athena M. Owen, and Joan R. Mylroie \\ Department of Geosciences, Mississippi State University, Mississippi State, MS 39762 USA, willapajames@hotmail.com,mylroie@geosci.msstate.edu, \\ dinosaurgoddess@yahoo.com,jmylroie@deanas.msstate.edu
}

\begin{abstract}
Coastal areas on carbonate islands commonly contain two types of caves: sea caves developed by wave erosion processes, and flank margin caves developed by dissolution at the edge of the fresh-water lens. Differentiating sea caves and flank margin caves in coastal settings is important, but can it be done reliably and quantitatively? Current methods use the degree of intricate wall-rock dissolution and the presence or absence of dense calcite speleothems to separate the two cave types. This study reports how analysis of cave maps creates three separate tools to differentiate coastal caves: area to perimeter ratio, entrance width to maximum width ratio, and rectangle short axis to long axis ratio. The study also presents some of the first sea cave data from eogenetic carbonate islands, specifically eolian calcarenites. The morphological and geometrical comparisons between Bahamian flank margin cave and sea cave maps using the three tools allows the two cave types to be statistically differentiated. The Bahamian sea cave data were also compared to sea cave data from California and Maine to demonstrate that Bahamian sea caves have a unique quantitative signature based on the youth and homogeneity of the host eolian calcarenite rock. The Bahamian sea cave data also indicate that sea cave formation may not be solely determined by differential rock weaknesses, as reported in the literature, but may also be a result of wave dynamics such as constructive interference.
\end{abstract}

\section{INTRODUCTION}

On carbonate islands such as the Bahamas, there exists a mechanism for producing dissolutional caves adjacent to coastlines at or near sea level. Dissolution occurs in the phreatic environment of a floating Ghyben-Herzberg-Dupuit fresh-water lens as a result of: 1) mixing with vadose fresh water descending to the lens, and mixing with phreatic marine water below the lens; 2) oxidation of organics trapped at the density interfaces at the top and bottom of the lens; and 3) the increased flow velocity associated with the distal lens margin (Mylroie and Mylroie, 2007). This dissolutional environment results in caves that are unique to these island/coastal carbonate settings. Termed flank margin caves (Mylroie and Carew, 1990), these caves exhibit a morphology that is very different from epigenic stream caves, but very similar to that observed in hypogenic caves (Mylroie and Mylroie, 2007; Palmer, 1991; 2007). As seen in Figures 1 and 2, flank margin caves commonly consist of oval chambers separated by thin bedrock walls, maze-like passages, undulating ceilings and floors, bedrock pillars, and complex wall morphology. The dissolutional bedrock morphology and interior deposits of flank margin caves lack evidence of highspeed turbulent flow, such as ablation scallops or sediment bedforms typical of epigenic stream caves (Mylroie and Carew, 1995).
Because the locations of flank margin caves are linked with sea-level position, they record Quaternary glacioeustatic sea-level changes in the tectonically-stable Bahamas. Most enterable flank margin caves are found at approximately 2-4 m above present sea level, which, after allowing for isostatic subsidence (Carew and Mylroie, 1995a), corresponds with the height of the last interglacial sealevel highstand $(\sim 125 \mathrm{ka}$, MIS $5 \mathrm{e})$. The caves are developed in Quaternary eolian calcarenites (or eolianites), composed of well-sorted, fine-grained sands lacking secondary structural features. A full discussion of Bahamian geology and karst processes can be found in Carew and Mylroie (1995b; 1997), Mylroie and Mylroie (2007), and Mylroie and Carew (2008).

Sea caves are also common features of the littoral zone on rocky coastlines with cliffs. Bahamian sea caves lack the internal complexity of flank margin caves (Figs. 3 and 4). In order for sea caves to form, Moore (1954) argued that: "The prerequisite conditions of [sea] cave formation are: 1) the presence of a sea cliff which is in direct contact with the erosive forces of waves and currents; 2) the exposed face of the cliff must contain certain geologic structures, or textures, which will allow the establishment of differential erosion; 3) the rock of which the cliff is composed must be of sufficiently resistant nature so as to prevent rapid formation of a protective beach at its base." A protective beach attenuates wave energy, and resistant rock allows for a sizeable cavity to form without collapse. Sea caves have 


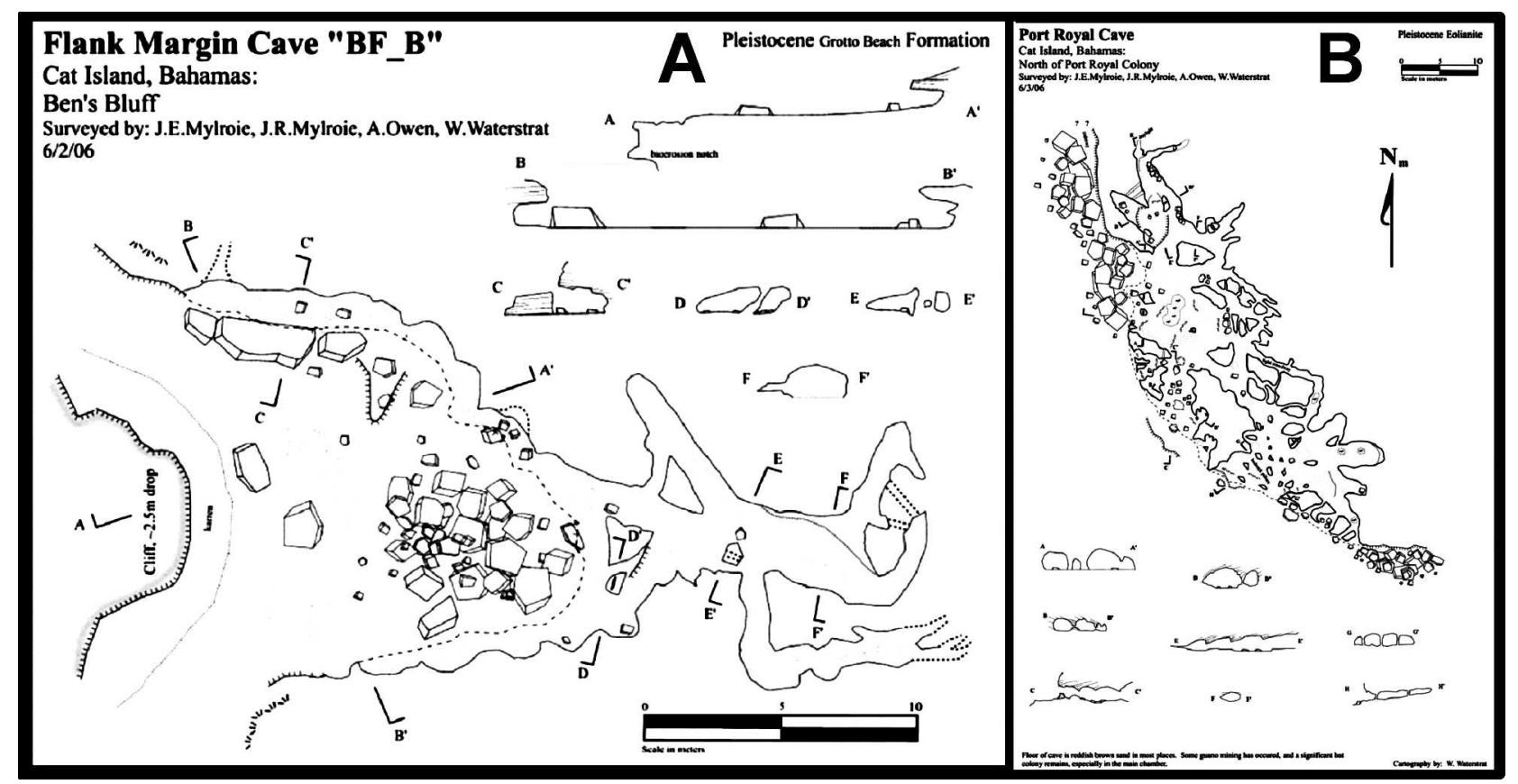

Figure 1. Maps of typical Bahamian flank margin caves currently located in coastal settings where wave action has breached into them. A) BF_B Cave, Cat Island, Bahamas. B) Port Royal Cave, Cat Island, Bahamas. Both caves were surveyed as part of the research for this paper and were added to the Roth (2004) Bahamian flank margin cave database.

therefore been considered to usually form when wave action exploits a pre-existing weakness of the rock, causing differential erosion to produce a cave. It is important to note that even in carbonate rocks, differential erosion is largely due to mechanical weathering and not necessarily to dissolution as in traditional karst caves. Weakness in the rock may be due to primary or secondary structures (Moore, 1954). Initial rock weaknesses caused by secondary structures such as joints and faults have a large effect on the shape, size, and extent of the resulting cave (Bunnell, 1988), as is clearly shown in the fault controlled, elongate sea caves of Santa Cruz Island (Fig. 5). However, in this study, Bahamian sea caves are shown to form in carbonate rocks with little or no existing secondary structural weaknesses. Eolianites are an extremely homogenous and uniform rock; their greatest heterogeneity occurs at their top contacts, where paleosols occur. Sea caves developing well below these paleosols are forming in a very uniform material.

Flank margin caves and sea caves form a cave category called coastal caves. As both cave types develop at or near sea level, they can be used for sea-level indicators. However, because flank margin caves are hypogenic in character (Palmer, 1991), and form without an entrance, they are only found when erosion and denudation has intersected them. Alternatively, sea caves must form along an actively eroding cliffline in a shoreline setting (Fig. 6). Sea caves are expressed in the surface environment as they originate, but flank margin caves are not expressed at the surface until some degree of subsequent surface denudation has occurred (Fig. 7).
The Quaternary has been a time during which sea levels have been lower than at present about $85 \%$ of the time, and flank margin caves found above sea level today formed within the short time window of Quaternary sea-level highstands (Mylroie and Mylroie, 2007). In the Bahamas, coastal caves that developed during past sea-level highstands (in the vicinity of today's sea-level elevation) have spent significant time in the subaerial environment during lower glacioeustatic sea levels. As a result, their exhumations are attributable to significant amounts of surface denudation (Fig. 7B). The degree of surface denudation can determine if a coastal cave is truncated or removed. Sea caves, forming open to the coast, are vulnerable to complete removal by a degree of surface denudation that would only truncate a flank margin cave developed at the same time (Fig. 7C). Therefore, successful differentiation between flank margin caves and sea caves can help document the degree of denudation (Fig. 7D). Because the time of cave formation is known (125 ka), the denudation rate can be estimated. Denudation is greatly affected by climate. Therefore, given that cave formation and denudation are so closely linked in time, the amount of denudation expressed by cave truncation and erosion is a paleoclimatic indicator.

Flank margin caves, because they form in the distal margin of the fresh-water lens, contain information about the configuration, discharge, and other properties of that lens. Flank margin cave configurations, sizes, and locations have been successfully used to determine past fresh-water lens properties in carbonate islands (Mylroie et al., 2008). 


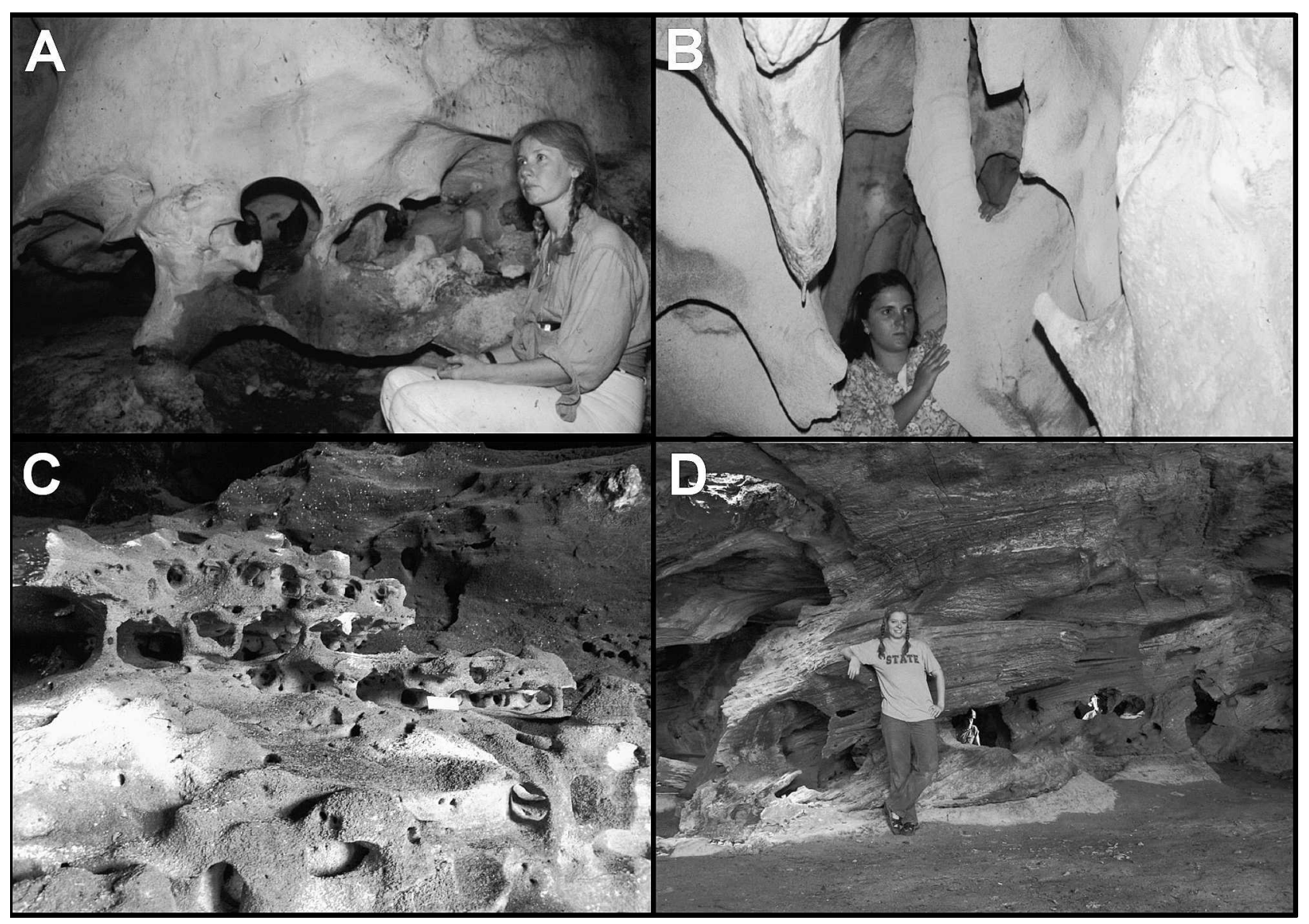

Figure 2. Images of dissolutional features typical of flank margin caves in the Bahamas and globally. Sea caves do not display the delicate bedrock sculpture seen here. A) Harry Oakes Cave, New Providence Island. B) Lighthouse Cave, San Salvador Island. C) Temple of Athena Cave, Crooked Island (scale bar is $10 \mathrm{~cm}$ long). D) Babylon Cave, Acklins Island; note figures visible through holes in the bedrock pillar.

The configuration of a fresh-water lens is controlled by rock properties such as porosity and permeability, and climate factors such as precipitation and evapotranspiration; if the rock properties are known, paleolens configuration can assist paleoclimatic interpretation. Therefore, determining whether a coastal cave is a flank margin cave or a true sea cave has important implications in regard to denudational processes, and as a result, paleoclimate for that region.

Speleothems have been used to differentiate sea caves from flank margin caves (Mylroie and Carew, 1991). Speleothems, especially calcite precipitates such as stalactites, stalagmites, and flowstone are usually diagnostic of development inside an enclosed cave environment. For well-ordered, dense calcite precipitation, the cave environment has to be atmospherically restricted enough to allow $\mathrm{CO}_{2}$ diffusion, as opposed to evaporation, to dominate the calcite precipitation. Open sea caves are unlikely to provide such an environment, whereas flank margin caves, especially prior to erosional breaching, do provide such an environment (Mylroie and Carew, 1991). In open, evaporative environments, calcite precipitates tend to be porous, crumbly and tuffaceous (Taboroši et al., 2006). Therefore, the existence of well-developed calcite speleothems in truncated cave chambers (Fig 8A), and even in remnant notches (Fig 8B), can be an indicator that denudational processes have breached a dissolutional cave. However, wave action on a small, breached flank margin cave could strip out speleothems, and lead an observer to an incorrect interpretation that the cave remnant was an abandoned sea cave. Sea caves in carbonate rocks, especially ones abandoned as a result of sea-level change or coastal dynamics, such as beach or spit formation, might be able to create a calcite precipitation environment, especially if the entrance has become restricted by sedimentation or breakdown. Speleothems in such caves could result in the cave being misinterpreted as dissolutional in origin. Some of the pitfalls in using calcite speleothems as indicators of cave origin are discussed in Taboroši et al. (2006). As with any scientific inquiry, multiple lines of evidence should be utilized to make an interpretation of sea cave versus flank margin cave origin. 


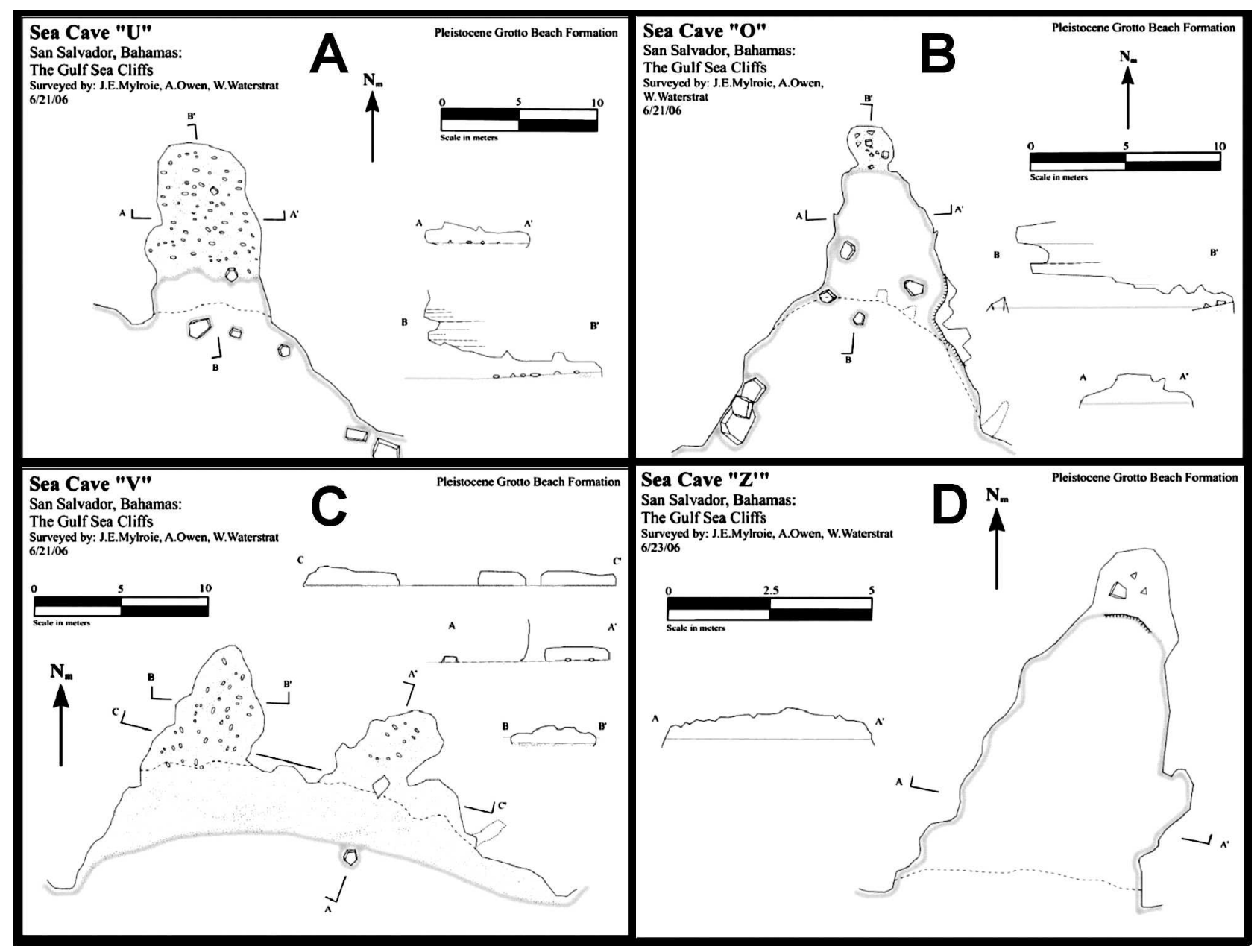

Figure 3. Maps of typical sea caves from San Salvador, Bahamas. Note the simplicity of the caves compared to Figure 1. All examples from the southern coast of San Salvador Island. A) Sea Cave "U". B) Sea Cave "O". C) Sea Cave "V". D) Sea Cave " $Z$ ".

The morphological parameters presented in this paper (Fig. 2 compared to Fig. 4), supported by independent evidence such as calcite speleothems, can strengthen the interpretation of coastal cave origin.

\section{Methodology}

Flank margin caves have been widely studied in recent years, and an extensive database of maps exists for them; 66 Bahamian flank margin cave maps were obtained from Roth (2004). However, sea caves, especially in carbonate rocks, have received little attention. There are numerous sea caves on the U.S. west coast and these have been documented in places such as the California Channel Islands (Bunnell, 1988). For this study, 98 maps of sea caves from Santa Cruz Island, California were scanned from Bunnell (1988). Additionally, eight sea caves (active and relict) from Mount Desert Island, Maine were scanned from Nardacci (2002). Forty-four Bahamian sea caves were surveyed and mapped on several trips to the Bahamas between 2005 and 2007, with the majority of them surveyed in June 2006. Additional flank margin caves were mapped on Cat Island, Bahamas, as part of this study (Fig. 1). The surveys were done with a fiberglass tape and Suunto compass and inclinometer, following the protocols of Dasher (1994). Sketches were done with a high degree of detail and accuracy because cave maps for both flank margin caves (Fig. 1) and sea caves (Fig. 3) were the basis for subsequent morphometric analyses.

In order to quantify the distinctions between flank margin caves and sea caves, a series of morphometric parameters were created (Roth, 2004; Roth et al., 2006; Waterstrat, 2007). From the cave maps, several measurements were taken: (1) perimeter (excluding the length of the entrance dripline); (2) area (enclosed by the walls and dripline); (3) entrance width; (4) maximum width (roughly parallel to entrance measurement); and (5) the length of the axes of the smallest possible rectangle to enclose the entire cave. These measurements are shown for a coastal cave map in Figure 9. Computer programs were used to 


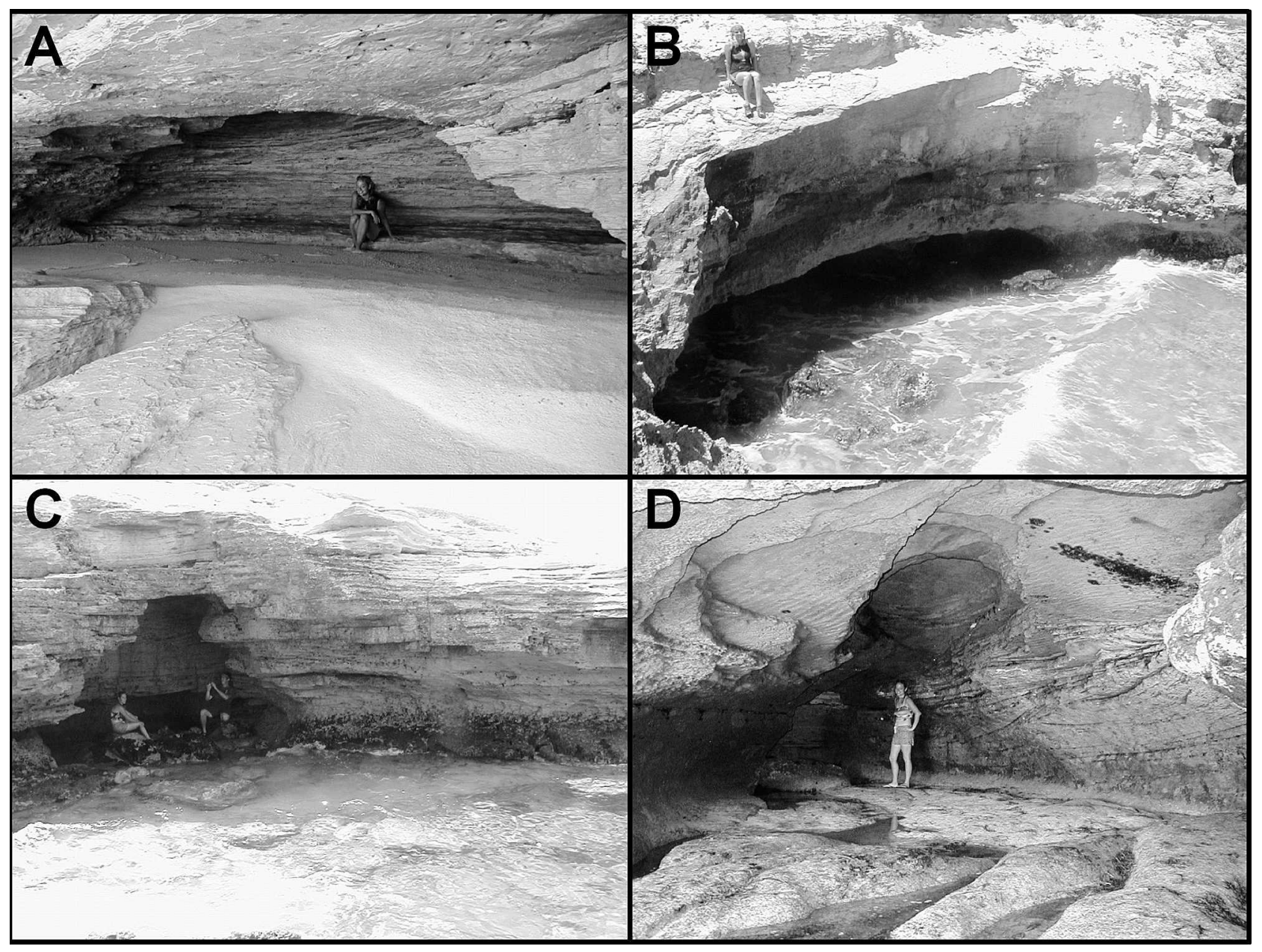

Figure 4. Images of typical sea caves from San Salvador Island, Bahamas. Note the large entrances, and the simplicity of the bedrock wall configuration as a result of mechanical carving by wave action. A) Sea cave in coastal cliffs north of Grotto Beach, southwest side of the island. B) Sea cave in coastal cliffs west of The Gulf, south side of the island. C) Sea cave in coastal cliffs at North Point, northeast side of the island. D) Sea Cave at Cut Cay, the truncated northern tip of North Point, northeast side of the island (note wind ripples exposed in the eolian beds of the cave roof). Sea caves shown in A and B are developed in Late Pleistocene beach, back beach and eolian calcarenites (Grotto Beach Formation). Sea caves shown in C and D are developed in Holocene eolian calcarenites (Rice Bay Formation). The sea caves in the Holocene rocks are unlikely to be breached flank margin caves, as the rocks have only been in existence for 5,000 years (Carew and Mylroie, 1995b; 1997), providing a control for the morphometric analysis of sea cave maps.

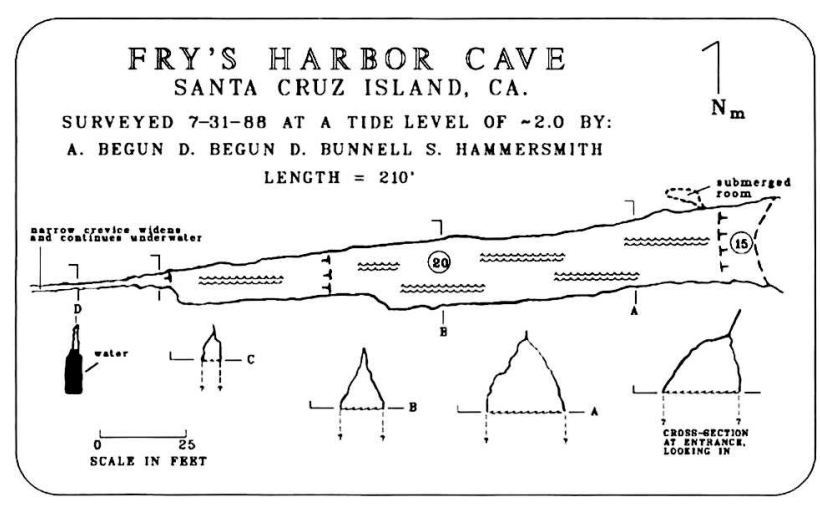

Figure 5. A Fault-controlled sea cave from Santa Cruz Island (after Bunnell, 1988). generate the cave area and perimeter values from scanned cave maps. Initially Autocad ${ }^{\circledR}$ was used by Roth (2004) for the 66 caves in her database. For this study NIH $1.62 \mathrm{f}$ (freely available software from the National Institutes of Health (NIH)) was used because it is a simple and faster program to operate. Comparison testing demonstrated the two programs produce identical results. Because these measurements are dependent on the overall size of the cave, they must be normalized to allow for comparisons of individual caves and groups of caves. Therefore, the following ratios were used: (1) area to perimeter ratio (A/ $\mathrm{P})$; (2) entrance width to maximum width (E/M); and (3) rectangle short/long axes (S/L). The use of these metrics, developed for sea cave/flank margin cave comparisons by 


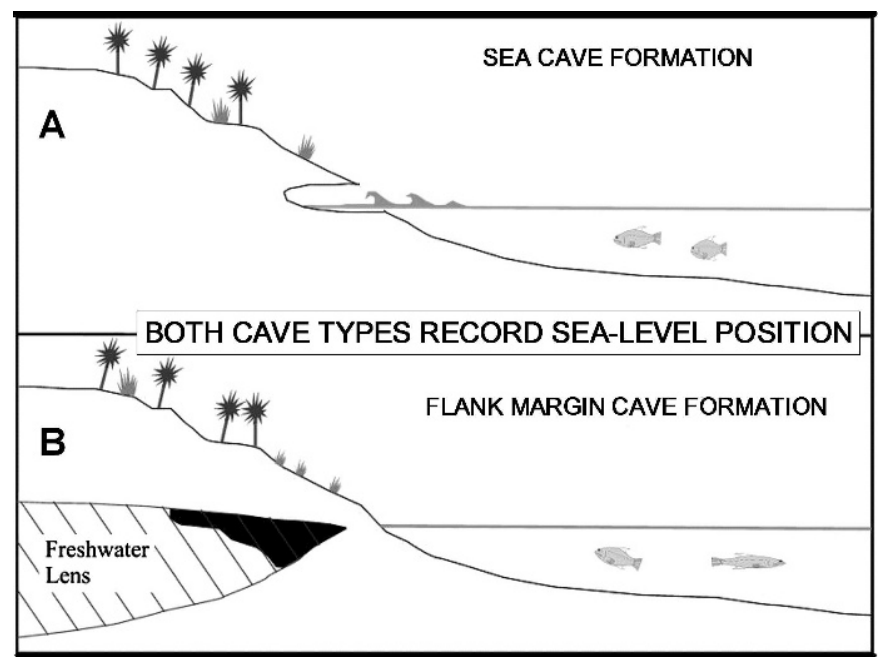

Figure 6. Diagram demonstrating the position of development of sea caves (A) and flank margin caves (B). Assuming the sea-level highstand shown is glacioeustatic from MIS 5e $\sim 125 \mathrm{ka}$, the events shown in Figure 7 can be considered.

Waterstrat (2007), have been successfully applied to a comparison of sea caves and flank margin caves on the limestones of coastal Puerto Rico (Lace, 2008). For this study, each comparison was first examined using analysis of variance, and a $t$-test was used to determine statistical significances ( $p$ values).

\section{Area to Perimeter Ratio (A/P)}

Coastal caves tend to be chambers and collections of chambers, rather than long linear features, as is typical of dendritic stream caves. As a result, areal footprint as determined from the cave map is the best measure of coastal cave size, as opposed to simply summing the length of survey shots as is commonly done for ranking the size of stream caves (Mylroie, 2007). Because of the way flank margin caves form (by intersection of ever-enlarging voids), they are expected to have a complex, and therefore long, perimeter for their individual area (Labourdette et al., 2007). As a result, the ratio of area to perimeter is an indication of the complexity of the perimeter. Flank margin caves are expected to have lower $\mathrm{A} / \mathrm{P}$ ratios, reflecting their complex perimeters (Figs. 1 and 2). Sea caves should have higher A/P ratios, which illustrates their less convoluted perimeters as a result of genesis by mechanical erosion because block detachment yields planar walls and wave abrasion smoothes wall irregularities (Figs. 3 and 4).

\section{Entrance Width to Maximum Width (E/M)}

Flank margin caves form with no entrance to the surface. They are expressed only when they have been breached by hillslope retreat, intersected by vadose shafts, or exposed by collapse (Figs. 7 and 8). Because of this phenomenon, a very large cave may have only a very small entrance. Sea caves, however, are dependent on wave energy for their formation, so the entrance is usually the widest point of the cave. Comparing the ratio of entrance width to maximum width yields values between zero and one. If the ratio is one, the entrance is the widest point of the cave, as expected for most sea caves. If the ratio is smaller than one, the entrance is narrower than the widest point of the cave. Ratios much smaller than one are expected for flank margin caves that are largely intact.

\section{Rectangle Short/Long Axes (S/L)}

For each cave map, a smallest-possible rectangle that would enclose the entire cave was created and the length of each axis recorded. By creating a ratio of the short axis over the long axis, values range from near zero to one. The more elongate a cave is, the lower this ratio becomes. As the ratio approaches one, the axes approach the same length, and therefore a square with no elongation. Because many sea caves in California are controlled by faults and joints (Bunnell, 1988), they were expected to yield low S/L values (Fig. 5).

\section{COMPARison CONTROLS}

In order to make quantitative comparisons, sea caves and flank margin caves had to be initially identified and characterized by other means. To establish origin as a flank margin cave, the maps from caves that could not be sea caves were utilized as controls. For example, if a flank margin cave was enterable only by a vertical dissolution shaft or vertical collapse, a sea cave origin was highly unlikely. The same could be said for a flank margin cave entered by way of a small entrance, which then opened into a very large chamber. Wave energy would not have been able to create such a chamber with only a single tiny orifice for wave energy access. The young age of flank margin caves (late Pleistocene), and their development as chambers within the fresh-water lens means that the cave walls are not masked by sediment, breakdown, or massive speleothems as is common in continental epigenic caves. The bedrock wall of a typical flank margin cave can be observed throughout the cave, and can demonstrate that there are no blocked, large entrances that could have once been used by wave energy. Dense calcite speleothems, and wall rock morphology (Fig. 2) provide additional independent evidence of dissolutional origin.

The control case for sea caves was provided by sea caves developed in Holocene eolianites on San Salvador. These Holocene eolianites are 5,000 years old or less (Carew and Mylroie, 1995b; 1997), and therefore, could not host relict flank margin caves from an earlier sea-level highstand.

For both sea caves and flank margin caves, the control cave set plotted separately in the quantitative study, allowing the unknown caves to be properly classified. Each unknown cave carried independent information, such as presence or absence of calcite speleothems, and complex or simple wall morphology, that supported the initial 


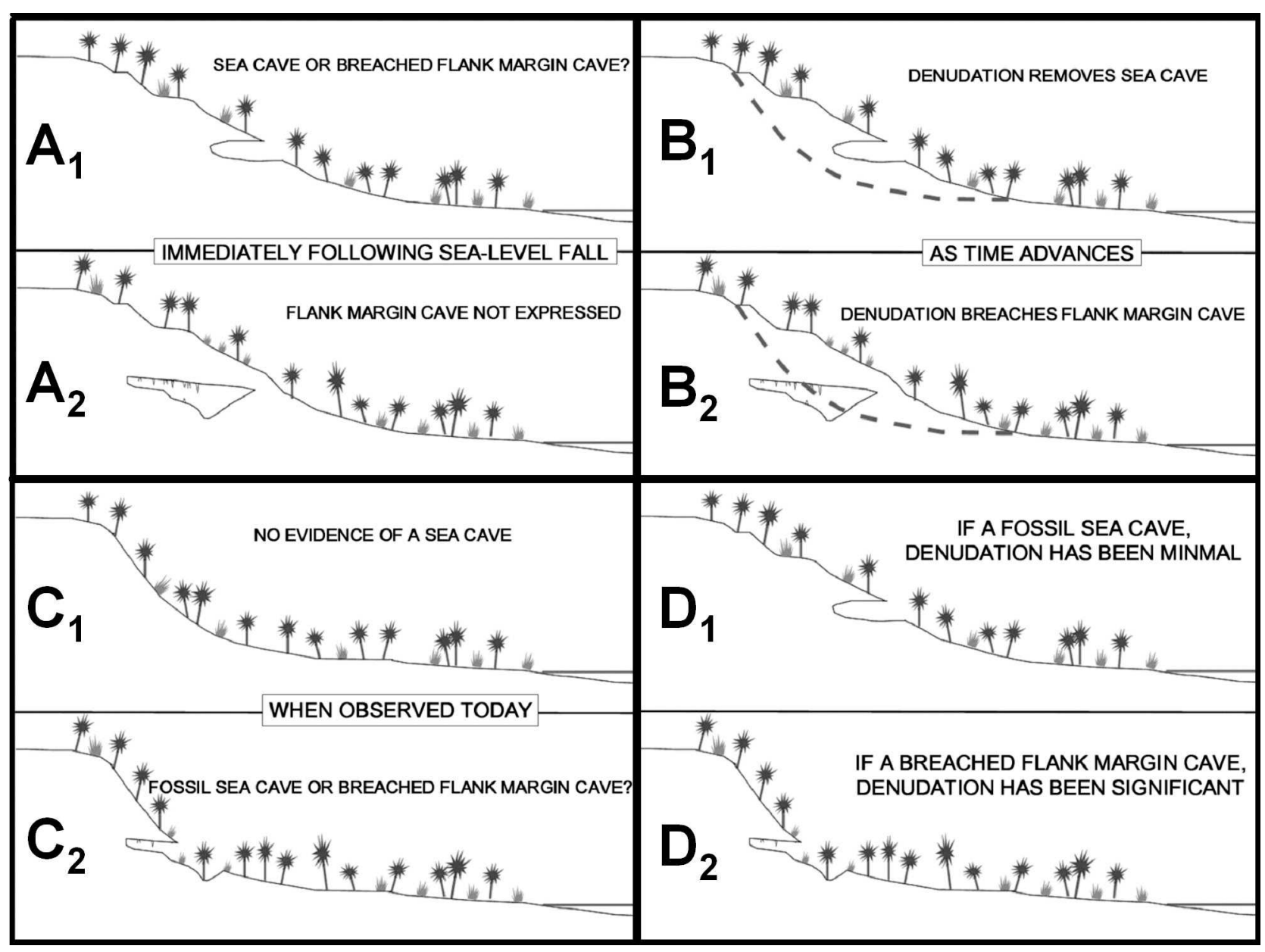

Figure 7. Sequential diagram to show the response of sea caves and flank margin caves to surficial denudation processes. A). Immediately following sea level fall (glacioeustatic in the Bahamas, after the end of MIS 5e), sea caves are expressed ( $\left.A_{1}\right)$, but flank margin caves are cryptic $\left(A_{2}\right)$. B) Denudation of meters to tens of meters (dashed line) completely removes sea caves $\left(B_{1}\right)$, and opens previously cryptic flank margin caves $\left(B_{2}\right)$. C) As a result of the denudation shown in $(B)$, no evidence remains of sea cave development $\left(C_{1}\right)$, and the caves remaining are breached flank margin caves $\left(C_{2}\right)$. D) If speleothem and morphometric analysis allow the cave types to be distinguished, then the amount of denudation, and therefore the paleoclimatic conditions necessary for that denudation, can be determined $\left(D_{1}\right.$ versus $\left.D_{2}\right)$.

classification based on the control set, and as will be shown, the quantitative morphology. As has been noted, breached flank margin caves in coastal zones can be invaded and modified by wave action, creating a transitional form. Also, a sea cave as it enlarges inland may intersect pre-existing karst features. An example is shown in Figure 9, where a small dissolution pit has been intersected by sea cave growth, seen in the northeast portion of the cave.

\section{RESUlts}

The cave maps used from all literature sources and from surveys conducted in the Bahamas are available online from Waterstrat (2007). The parameters presented above were used to compare Bahamian flank margin caves with sea caves from San Salvador, because they occur in the same rock types. Sea caves from California and Maine were also compared to sea caves from San Salvador to examine potential cave differences caused by different rock types and locations. These latter two groups form in crystalline rocks and are structurally controlled to varying degrees. San Salvador sea caves, however, form in Quaternary carbonates without guiding secondary structural weaknesses (Mylroie and Mylroie, 2009). The ability of this technique to distinguish between cave types is demonstrated below.

\section{Area to Perimeter Ratio (A/P)}

As previously mentioned, area to perimeter ratio is a measure of the complexity of the perimeter for a given size (based on area) of cave. Area to perimeter ratio is useful for differentiating between Bahamian flank margin caves (FM) and San Salvador sea caves (SSSC), between San 


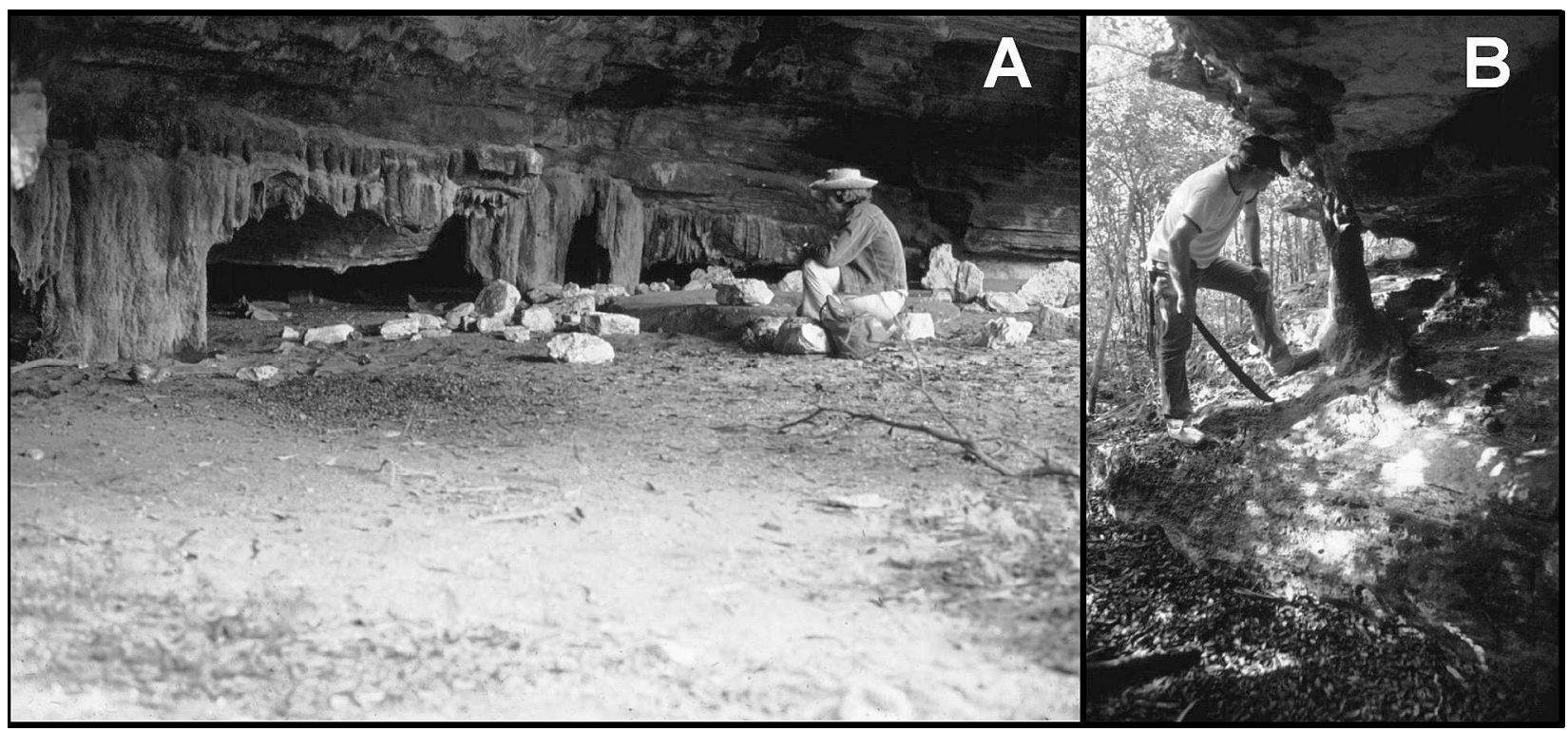

Figure 8. Relict calcite vadose speleothems visible in open caves and notches from an inland area at Grotto Beach, San Salvador Island, Bahamas. A) Dripping Rock Cave, with massive stalactites partially entombed in recent sands. B) Calcite column at Pink Grotto Cave, fully exposed to the open. This area was initially mapped as containing a fossil bioerosion notch (B) with fossil sea caves (A), but has been reinterpreted as breached flank margin caves (Mylroie and Carew, 1991; Florea, et al., 2004).

Salvador sea caves and Santa Cruz sea caves (SCSC), and between San Salvador sea caves and Maine sea caves (MSC), with greater than 95\% confidence (Table 1). Santa Cruz sea caves and Maine sea caves can be distinguished with $>90 \%$ confidence using $\mathrm{A} / \mathrm{P}$ values.

The four cave groups can be distinguished when $\mathrm{A} / \mathrm{P}$ values are plotted against cave areas (i.e., cave sizes) (Fig. 10). Examining only the Bahamian flank margin caves that are within the $300-\mathrm{m}^{2}$-size range (the typical size range of San Salvador sea caves, representing 41 flank

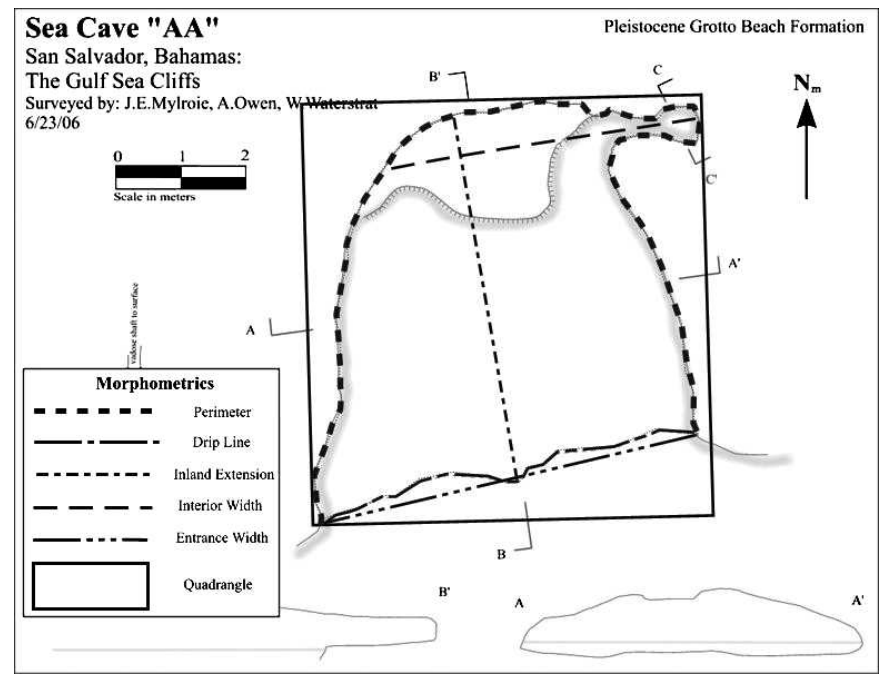

Figure 9. Map of Sea Cave AA, showing how perimeter, area, entrance width, interior cave width, inland extension, and enclosing box length and width were measured. margin caves) (Fig. 11), the San Salvador sea caves have a higher $\mathrm{A} / \mathrm{P}$ values than Bahamian flank margin caves. This result shows that for a given area, the perimeter of the San Salvador sea caves is smaller (therefore smoother), which is expected for voids generated by wave energy.

Area to perimeter $(\mathrm{A} / \mathrm{P})$ ratio is one of the best tools for differentiating between the various cave types. When comparing ratios for flank margin caves and the sea caves of San Salvador, they are distinct with better than 95\% confidence $(p=0.012)$, based on the Student's $t$-test. Differentiating between the various sea caves from different regions (San Salvador, Santa Cruz California, and Maine) is also possible. The $\mathrm{A} / \mathrm{P}$ ratio shows that San Salvador sea caves are distinct from Santa Cruz sea caves with more than $99 \%$ confidence $(p=0.001)$. Maine sea caves are found to be distinct from San Salvador sea caves with more than $95 \%$ confidence $(p=0.016)$. Finally, Santa Cruz sea caves are distinct from Maine sea caves with $\sim 95 \%$ confidence $(p=0.063)$.

\section{Entrance Width vs. Maximum Width (E/M)}

The entrance width vs. maximum interior width parameter (E/M ratio) is an indicator of the type of cave origin. Flank margin caves form with no entrance, and are entered only by later erosional intersection, so are expected to have small E/M values. Sea caves usually have relatively wide entrances because they form by mechanical erosion, and wave energy attenuates further into the cave, which limits littoral erosive power and typically leads to generally an inland tapering of sea caves (Moore, 1954). However, flank margin caves may have wide entrances if enough 
Table 1. Area to perimeter ratio differentiation results. $\mathrm{FM}=$ Flank Margin; $\mathrm{SSSC}=\mathrm{San}$ Salvador Sea Cave; $\mathrm{SCSC}=\mathrm{Santa}$ Cruz Sea Cave; and MSC = Maine Sea Cave.

\begin{tabular}{lcccc}
\hline A/P Ratio & FM vs. SSSC & SSSC vs. SCSC & SSSC vs. MSC & SCSC vs. MSC \\
\hline$p$ value & 0.012 & $5.4 \times 10^{-16}$ & 0.016 & 0.063 \\
Mean & $2.26 / 1.67$ & $1.668 / 3.954$ & $1.668 / 2.610$ & $3.954 / 2.610$ \\
Std. Dev. & $1.642 / 0.735$ & $0.735 / 2.191$ & $0.735 / 1.681$ & $2.191 / 1.681$ \\
\hline
\end{tabular}

erosion has occurred to breach into a large cave chamber. This parameter is useful for differentiating between all groups except San Salvador sea caves and Maine sea caves with better than $95 \%$ confidence (Table 2). San Salvador sea caves and Maine sea caves have a similar E/M morphology despite being found in rocks of different types and ages.

Only a few Bahamian flank margin caves have an E/M value of one (Fig. 12). Most flank margin caves are shown to have a much lower E/M value than San Salvador sea caves (mean $=0.524$ for flank margin caves, 0.933 for San Salvador sea caves). Using this parameter, these two caves types can be differentiated with better than 99\% confidence. Other groups (with the exception of Maine sea caves vs. San Salvador sea caves) can be confidently differentiated with this parameter as well.

\section{Rectangle Short/Long Axes (S/L)}

The rectangle measurement is described in the methodology section. Once again, the size of the rectangle is a measurement of cave size because it depends on area. Thus, in order to use this measurement for comparison, we examine the ratio of the lengths of the short and long axes

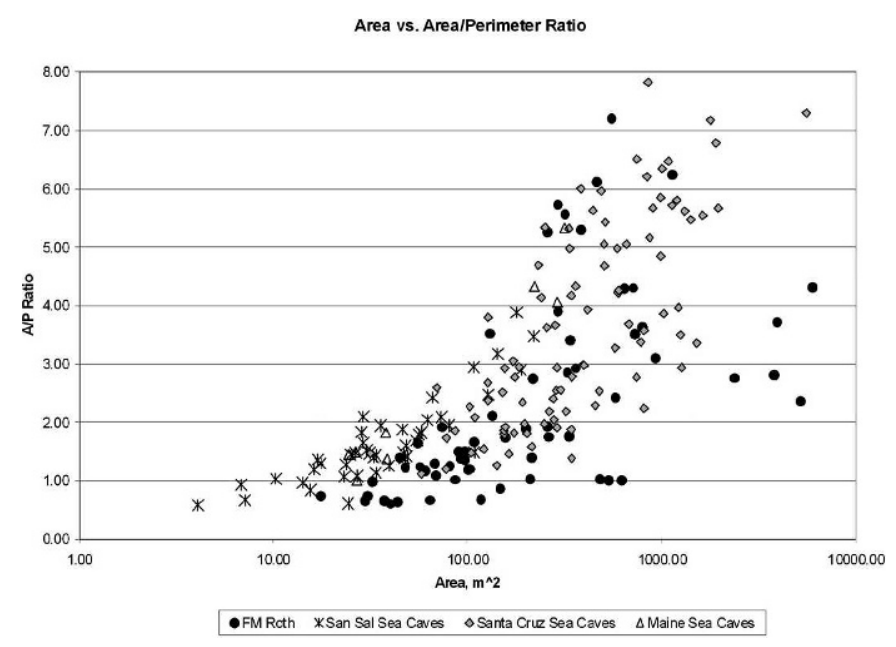

Figure 10. A/P vs. Area. Cross patterns are San Salvador sea caves, solid circles are Bahamian flank margin caves, filled diamonds are Santa Cruz sea caves, and light triangles are Maine sea caves. Visually, the separation of Bahamian flank margin caves (solid circles) from Bahamian sea caves (cross pattern) and Maine sea caves (open triangles) is apparent, but isolated overlaps occur. Statistics shown in Table 1. of the rectangle (Table 3 ). With a square rectangle, the ratio will be 1 . As the rectangle becomes exceptionally elongate, the ratio approaches zero. When we examine only those caves with an area of less than $300 \mathrm{~m}^{2}$ (Fig. 13), differences are apparent. In Figure 13, the ratio has been reversed, with long axis over short axis to allow a greater separation of the points for visual analysis. In this figure presentation mode, Santa Cruz sea caves commonly exhibit large long axis to short axis ratios, which is a reflection of their fault-controlled elongation.

Based on S/L ratio, Bahamian flank margin caves are distinct from San Salvador sea caves with $99 \%$ confidence. Flank margin caves have a lower mean ratio ( 0.535 for flank margin caves vs. 0.701 for San Salvador sea caves). When comparing the various types of sea caves, this metric also does an excellent job in distinguishing between the elongate, fault-controlled sea caves of Santa Cruz Island and the other less-elongate sea caves from San Salvador, but not as well with sea caves from Maine.

\section{DisCUSSION}

\section{Bahamian Flank Margin Caves vs. San Salvador Sea Caves}

Bahamian flank margin caves are distinct in shape from the sea caves of San Salvador. As predicted, the A/P ratio for Bahamian flank margin caves is significantly lower than

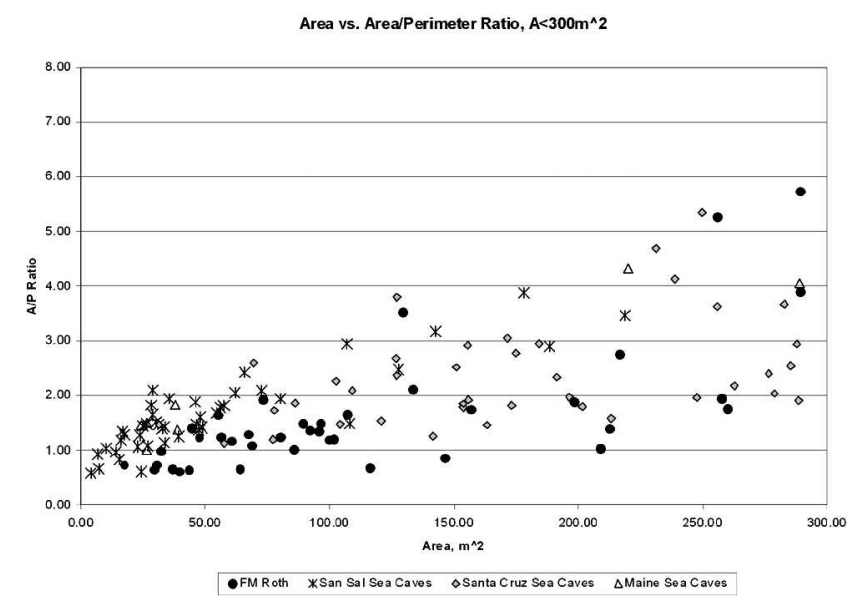

Figure 11. A/P vs. Area for caves $<300 \mathrm{~m}^{2}$. Cross patterns are San Salvador sea caves, solid circles are Bahamian flank margin caves, filled diamonds are Santa Cruz sea caves, and light triangles are Maine sea caves.

Journal of Cave and Karst Studies, August 2010•69 
COASTAL CAVES IN BAHAMIAN EOLIAN CALCARENITES: DIFFERENTIATING BETWEEN SEA CAVES AND FLANK MARGIN CAVES USING QUANTITATIVE MORPHOLOGY

Table 2. Entrance width vs. maximum width results. FM = Flank Margin; SSSC = San Salvador Sea Cave; SCSC = Santa Cruz Sea Cave; and MSC = Maine Sea Cave.

\begin{tabular}{lcccc}
\hline E/M Ratio & FM vs. SSSC & SSSC vs. SCSC & SSSC vs. MSC & SCSC vs. MSC \\
\hline$p$ value & $3.7 \times 10^{-13}$ & $1.8 \times 10^{-4}$ & 0.38 & $7.2 \times 10^{-4}$ \\
Mean & $0.524 / 0.933$ & $0.933 / 0.803$ & $0.933 / 0.968$ & $0.803 / 0.968$ \\
Std. Dev. & $0.349 / 0.148$ & $0.148 / 0.250$ & $0.148 / 0.090$ & $0.250 / 0.090$ \\
\hline
\end{tabular}

that of San Salvador sea caves. Given two caves of the same size, a flank margin cave is expected to have a more complex (i.e., longer) perimeter, which reflects its dissolutional formation by intersection of ovular voids (Figs. 1 and 2). Sea caves are expected to have much smoother walls, and therefore, shorter perimeters (Figs. 3 and 4). Thus, when comparing the $\mathrm{A} / \mathrm{P}$ ratios for these two cave types, flank margin caves should have a lower ratio than a sea cave of the same size (area). However, smaller flank margin caves often have a rather simple perimeter. This is because they may only form by the enlargement and intersection of a few voids, instead of many. Small flank margin caves, when breached by wave action, are also more likely to experience wave scour of their entire interior, which can remove some passage wall complexity (and speleothems). Though most of the San Salvador sea caves fall within this small size range $\left(<300 \mathrm{~m}^{2}\right)$, they can still be shown to be distinct from flank margin caves, even though Figure 10 shows that sea caves and flank margin caves plot closer together when they are smaller in area.

The techniques described in Waterstrat (2007), using area and perimeter measurements to differentiate seas caves and flank margin caves has, as noted earlier, been adapted (Fig. 14) to coastal carbonates on Puerto Rico

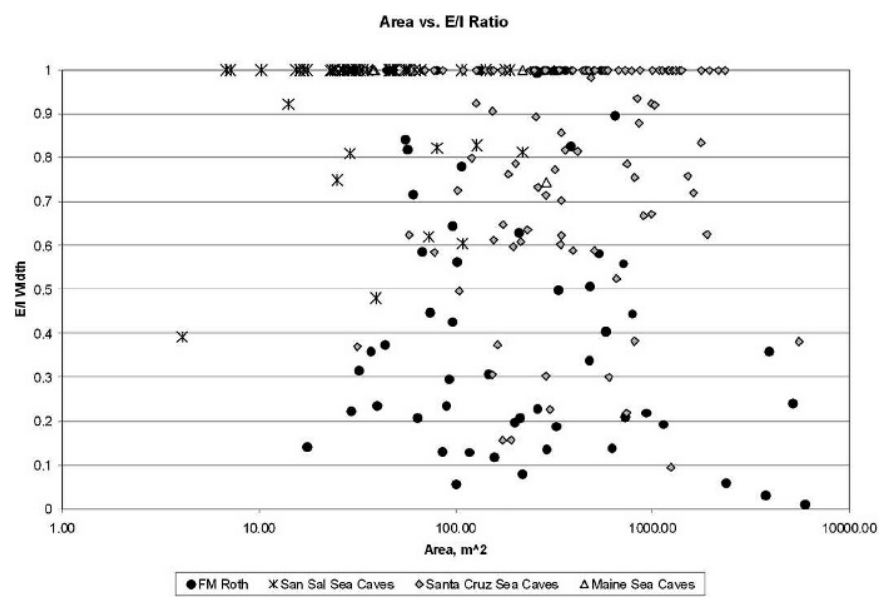

Figure 12. E/M vs. Area. Note that few Bahamian flank margin caves have an E/M ratio near 1. Cross patterns are San Salvador sea caves, solid circles are Bahamian flank margin caves, filled diamonds are Santa Cruz sea caves, and light triangles are Maine sea caves. Statistics shown in Table 2.
(Lace 2008, his Fig. 6). Lace (2008) arranged his plots slightly differently, placing perimeter on the vertical axis and area on the horizontal axis, but the results plot similar to the $\mathrm{A} / \mathrm{P}$ ratio versus area graphs shown in this paper (e.g. Figs. 10 and 11). This entirely independent study has demonstrated that sea caves and flank margin caves can be reliably differentiated from maps of similar areal footprint in a coastal carbonate setting other than in the Bahamas. Note that as cave size decreases, differentiating Puerto Rican sea caves from flank margin caves becomes more difficult, for reasons noted previously.

The ratio of the short and long axes of the rectangle is also a useful parameter for differentiating between Bahamian flank margin caves and San Salvador sea caves. Flank margin caves tend to have a smaller ratio. This means that they tend to be more elongate than San Salvador sea caves. This elongation is a function of the dissolutional formation of flank margin caves and their dependence on the freshwater lens position. Because the lens position and mixing front are dependent on sea level and distance to the coastline, flank margin caves are more likely to extend laterally along the coast than to extend inland, in order to follow the geochemically-active lens margin (Labourdette et al., 2007). This coast-parallel development is illustrated by several flank margin caves that wrap around the coastline, yet do not extend far inland (Mylroie and Mylroie, 2007). The sea caves of San Salvador, however, form voids that are enclosed by a less elongate rectangle. There is an apparent visual trend in Figure 13 for smaller flank margin caves to have an axis ratio closer to one. This result is a consequence of their small area not showing elongation parallel to the lens margin because the caves are not large enough to have exceeded the landward dimensions of the favorable lensmargin dissolution zone. As they get larger, they can link up only parallel to the coast and the inland limit of growth forces the lateral elongation. The size distribution of flank margin caves with an axis ratio close to one may indicate the width of the geochemically-active zone of the lens margin, a demonstration of lens dynamics and potentially paleoclimate at the time of cave development.

The ratio of entrance width to maximum interior width was the next parameter examined to differentiate cave types. When the entrance width is the widest point of the cave, the ratio is one. When entrances are small compared to the maximum interior width, the ratio approaches zero. Most San Salvador sea caves have a ratio of nearly one 
Table 3. Rectangle short/long axes ratio results. $\mathrm{FM}=$ Flank Margin; $\mathrm{SSSC}=$ San Salvador Sea Cave; $\mathrm{SCSC}=\mathrm{Santa}$ Cruz Sea Cave; and MSC = Maine Sea Cave.

\begin{tabular}{lcccc}
\hline S/L Ratio & FM vs. SSSC & SSSC vs. SCSC & SSSC vs. MSC & SCSC vs. MSC \\
\hline$p$ value & $1.2 \times 10^{-5}$ & $8.2 \times 10^{-9}$ & 0.028 & 0.44 \\
Mean & $0.535 / 0.701$ & $0.701 / 2.88$ & $0.701 / 0.547$ & $2.88 / 0.547$ \\
Std. Dev. & $0.204 / 0.171$ & $0.171 / 1.873$ & $0.171 / 0.207$ & $1.873 / 0.207$ \\
\hline
\end{tabular}

$($ mean $=0.933)$, reflecting the observation that their entrances are almost always the widest point of the cave. Flank margin caves are expected to have a smaller value because they can be large voids with small entrances formed from breaching by hillslope retreat or vadose intersection (pit entrances). However, in some cases, more than half of a flank margin cave may have been eroded away. In these instances, the entrance becomes the widest point. Significant denudation of flank margin caves (E/M 1) was demonstrated on Tinian Island, Marianas, as shown in Figure 15 (Stafford et al., 2005, modified from their Fig. 11), by use of entrance versus maximum width ratios. Apparently, most of the Bahamian flank margin caves in this study are not this extensively eroded, because their $\mathrm{E} / \mathrm{M}$ values are low (mean $=0.524$ ). The Tinian carbonates are older than those in the Bahamas and have been tectonically uplifted so their probable ages are likely greater, or the local climate creates a faster denudation rate (Stafford et al., 2005).

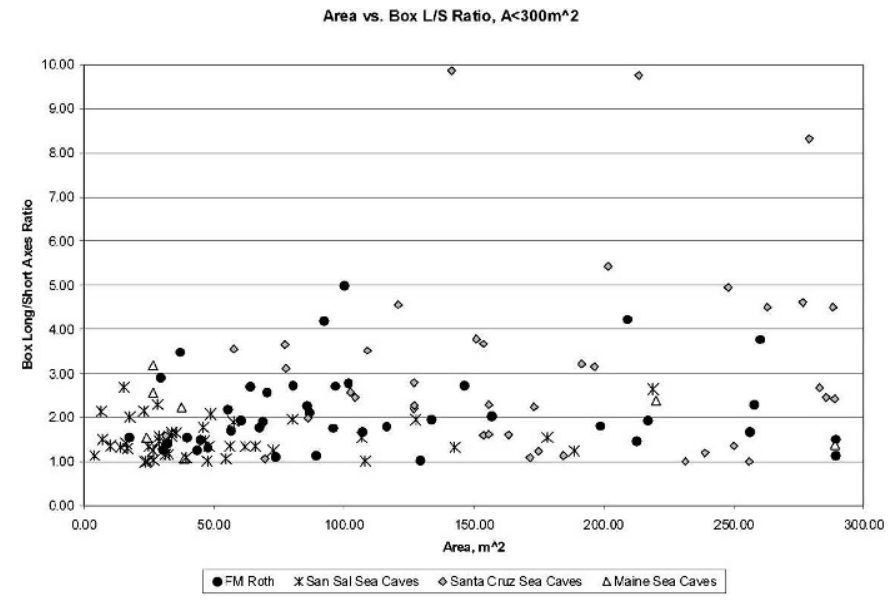

Figure 13. Area vs. L/S for caves less than $300 \mathrm{~m}^{2}$; the ratio has been inverted to increase visual separation of points. Note that Santa Cruz sea caves tend to have higher ratios with this inverted ratio presentation of long axis over short axis, reflecting their fracture elongation. Bahamian and Maine sea caves show a lack of elongation. Cross patterns are San Salvador sea caves, solid circles are Bahamian flank margin caves, filled diamonds are Santa Cruz sea caves, and light triangles are Maine sea caves. Statistics shown in Table 3.
San Salvador Sea Caves vs. Santa Cruz Sea Caves Because all sea caves form mostly by the erosive action of littoral wave energy, it might be expected that they will have similar morphologies. However, structural controls can have a considerable effect on their morphology. The sea caves of Santa Cruz occur in extensively faulted and jointed rocks. This preexisting weakness strongly guides their morphology and results in many long, linear caves (Bunnell, 1988). Their A/P values are then much different from that of the San Salvador sea caves and they can be readily differentiated.

Additionally, Santa Cruz sea caves exhibit smaller ratios of $\mathrm{S} / \mathrm{L}$ values for the rectangle fitting procedure, which reflects the elongation of many caves there. This again illustrates their fault/joint-controlled morphology. The penetrative faulting and related jointing creates a weakness that is readily exploited by wave energy, in otherwise resistant rocks. This results in generally elongate caves. Sometimes several faults are involved and the cave morphology becomes more complex, but the faults still

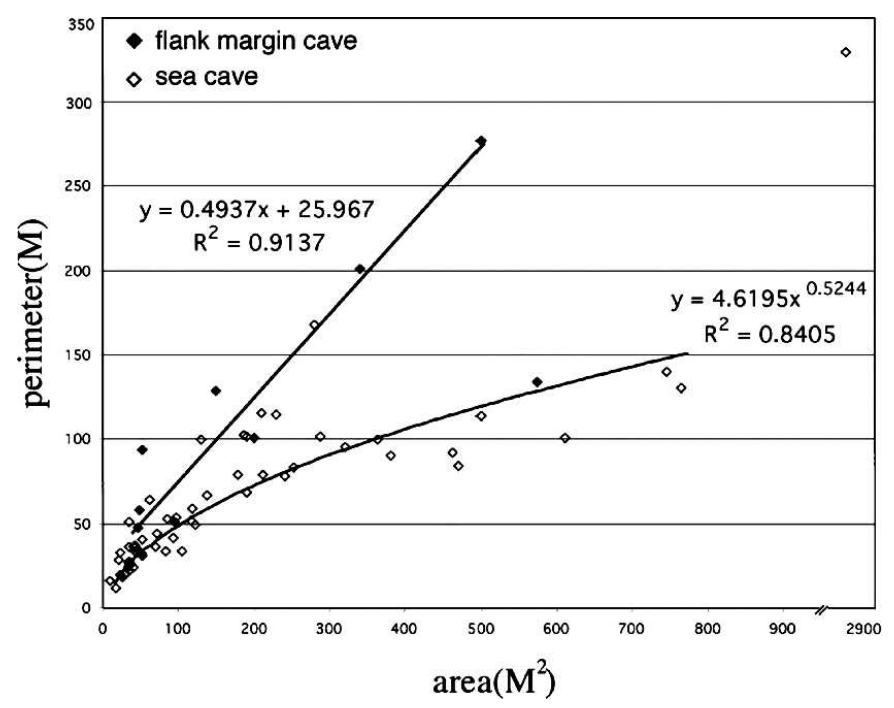

Figure 14. Plot of cave perimeter versus cave area for coastal caves of Puerto Rico, using the protocols established by Waterstrat (2007). Flank margin caves are solid diamonds, sea caves are open diamonds. Note the divergence of the plots as cave size increases (after Lace, 2008, his figure 6). Note also that cave perimeter is on the vertical axis, and cave area on the horizontal axis in this plot.

Journal of Cave and Karst Studies, August 2010 • 71 


\section{FLANK MARGIN CAVES, TINIAN ESCARPMENTS}

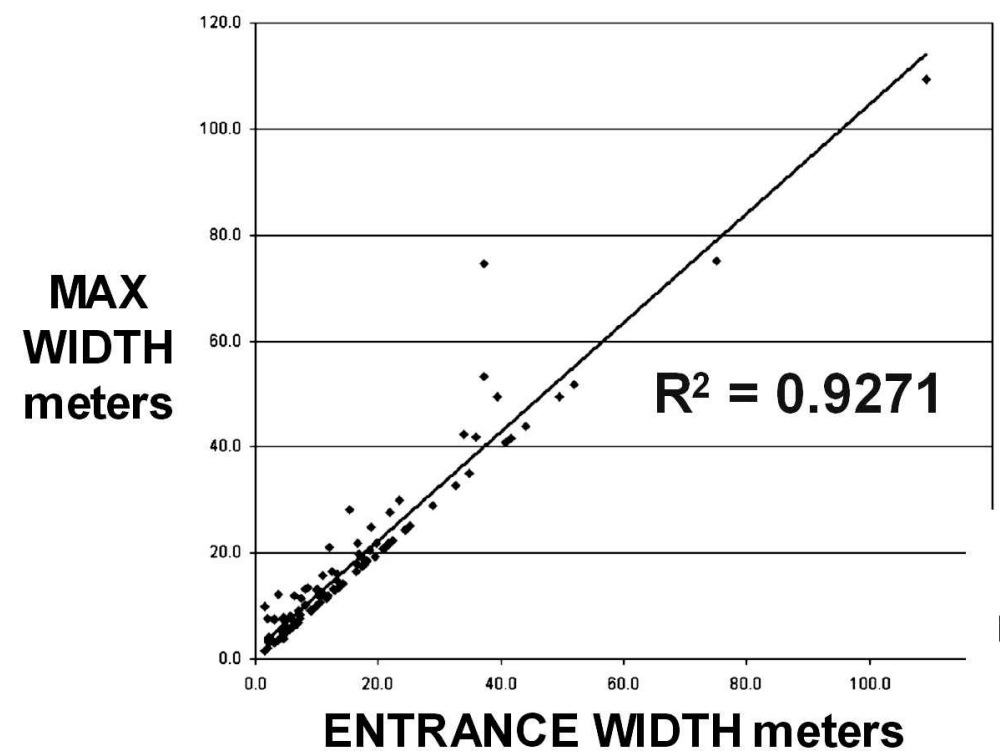

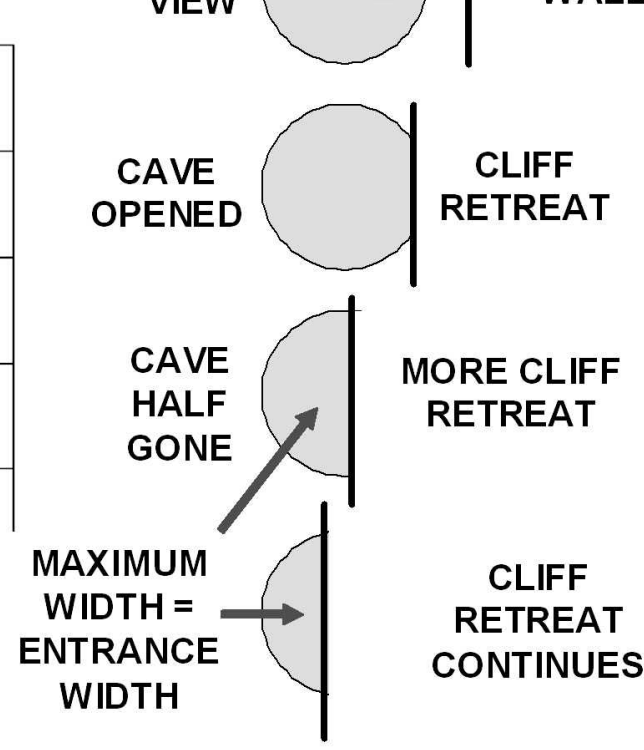

Figure 15. Plot of maximum width versus entrance width for flank margin caves on Tinian Island, Commonwealth of the Northern Mariana Islands. There are no points in the lower right hand portion of the graph because no cave can have an entrance width greater than its maximum width. A few caves plot in the upper left, indicating that the interior chamber is wider than the entrance. The vast majority of caves fall on the $45^{\circ}$ line, indicating that the cave is $50 \%$, or more, denuded such that the maximum width is the entrance width. Modified from Stafford et al. (2005). Tinian flank margin caves are denuded to a greater degree than in the Bahamas.

apparently guide their formation. Because the host rocks are otherwise resistant, the largest documented sea caves in the world are found here. Santa Cruz sea cave elongation is oriented inland; San Salvador flank margin cave elongation is oriented parallel to the coast.

$\mathrm{E} / \mathrm{M}$ values also proved valuable for differentiating these two cave types. A number of the Santa Cruz caves have multiple entrances and can have intersecting passages. Though many Santa Cruz Caves simply taper in width from their entrance to the back wall (resulting in an E/M ratio of 1; see Fig. 5), some of them are long and narrow, but open up into a larger chamber at the intersection of faults. Painted Cave, the largest sea cave in the world, is a good example of this phenomenon (Bunnell, 1988) These intersections helps explain why Santa Cruz sea caves have a lower $\mathrm{E} / \mathrm{M}$ value $($ mean $=0.803)$ than most San Salvador sea caves, which have a ratio close to $1($ mean $=0.933)$. San Salvador sea caves have a consistent morphology that simply tapers in width inward from the maximum width at the entrance.

\section{San Salvador Sea Caves vs. Maine Sea Caves}

Despite what at first glance appears to be similar morphology, San Salvador sea caves and Maine sea caves proved to be significantly different. Both of these groups of caves are formed in rocks that, as in the Bahamas are either absent of apparent guiding structural features like faults or joints, or as in Maine, have only a few such features. They exhibit a generally rectilinear outline with the entrance as the widest point. Despite these similarities, they are still distinguishable from each other by $\mathrm{A} / \mathrm{P}$ values, and the $\mathrm{S} / \mathrm{L}$ values. However, E/M values are not a good means of differentiating between these two cave types.

\section{Santa Cruz Sea Caves vs. Maine Sea Caves}

Comparing Santa Cruz sea caves with Maine sea caves is useful for illustrating the importance of joint control on the morphology of sea caves. Both groups are formed in broadly similar rocks (i.e., crystalline), yet they exhibit distinctly different morphologies. As previously mentioned, Santa Cruz sea caves are fault/joint-controlled and tend to be very elongate, although some complexity exists. Maine sea caves are formed in rocks that, while they may contain a fault or a dike, are absent of extensive jointing and exhibit a less elongate overall shape. These differences reflect the active (Santa Cruz) versus passive (Maine) tectonic setting of these two locations. Despite these apparent differences and average $\mathrm{S} / \mathrm{L}$ values (2.88 for Santa Cruz caves, 0.547 for Maine sea caves), they are not significantly different according to the $t$-test performed. This is surprising, but is probably explained by the very different sample sizes (98 Santa Cruz caves, 8 Maine caves). 
The $\mathrm{A} / \mathrm{P}$ values and the $\mathrm{E} / \mathrm{M}$ values have been shown to be useful for telling these two caves apart.

The Quaternary eolianite geology of the Bahamian sea caves is quite different from that of the harder, denser, and more structurally deformed rocks that make up the sea caves in Maine and the California channel islands. It is thus no surprise that differences in sea cave shape result.

\section{Conclusions}

This study makes comparisons between flank margin caves and various types of sea caves. Forty-four sea caves were surveyed and mapped on San Salvador. Additionally, three coastal flank margin caves were surveyed and mapped on Cat Island, Bahamas and added to the existing Roth (2004) database. Various morphometrics (perimeter, area, dripline length, entrance width, maximum interior width, and inland extension) were measured for comparison between caves.

The new sea cave data were compared to an existing and updated morphometric database for flank margin caves compiled by Roth (2004). Both coastal cave types developed in the same rocks and in similar environments, but formed by entirely different processes. Because of their coastal localities (including former shorelines from a previous highstand), these coastal caves are easy to misinterpret. However, the use of morphometric techniques allowed for confident differentiation between these two coastal cave types.

Cave maps were obtained for 98 sea caves in California (Bunnell, 1988) and eight sea caves from Maine (Nardacci, 2002). These sea caves are formed in crystalline rocks and perhaps are not comparable to flank margin caves developed in soluble rocks. However, the California and Maine sea caves form by the same littoral processes as the San Salvador sea caves (Waterstrat, 2007). Traditionally, sea cave morphology has been explained by differential susceptibility of the rock to erosion (e.g., faults and joints) (Moore, 1954). The Santa Cruz sea caves are extensively faulted and jointed and their morphology has clearly been guided by these structures, as illustrated by their pronounced elongation. The sea caves of San Salvador, however, contain none of these initial weaknesses so some other method must explain their formation. The same appears to be true with Maine sea caves, although sufficient field observations have not been conducted to verify this. Therefore, some other process must be responsible for the differential erosion that results in sea cave formation at specific locations on a uniform coastline like San Salvador. It is unlikely that all the sea caves found on San Salvador are breached and modified flank margin caves because so many sea caves occur in Holocene rocks, which are too young to contain flank margin caves. The morphometric analyses reported here agree with traditional techniques, such as wall morphology and speleothem presence, used to separate the two cave types. Wave focusing as a result of interaction with submerged topography, constructive and destructive wave interference, wave refraction, and wave diffraction might be the mechanisms. Previous sea cave classification has been based on secondary structural controls such as faults and joints, but this study has shown that sea caves form in Bahamian eolianites lacking such structures. As in hydrology, the properties of the water (e.g., water viscosity in aquifers, wave energy for sea caves) need to be considered as well as the rock properties. Porosity and permeability are not enough to explain groundwater flow in an aquifer; in a like manner, rock structure alone is not enough to explain sea cave formation in coastal cliffs.

All four groups of caves in this study were found to be distinct from each other using several morphometric parameters. This outcome reinforces the usefulness of these tools in the classification of coastal caves. Coupled with interior bedrock sculpture and speleothem occurrence, flank margin caves can be differentiated from sea caves by morphometric techniques, and the paleoclimatic information carried by each coastal cave assessed. Recent increased interest in sea caves, and the maps produced (e.g., Bunnell, 2008; 2009), may allow a larger sea cave database to be assembled. From such data, questions concerning rock qualities versus wave energy in the generation of sea caves can be assessed.

\section{ACKNOWLEDGMENTS}

The authors acknowledge the Gerace Research Centre, San Salvador Island, Bahamas, for logistical support of field operations. Mississippi State University supplied resources to support the research. Dave Bunnell, Pat Kambesis, and Mike Lace provided important input to the project. Lee Florea and an anonymous reviewer made many useful suggestions that improved the manuscript.

\section{REFERENCES}

Bunnell, D., 1988, Sea caves of Santa Cruz Island, Santa Barbara, Cal., McNally and Loftin, $123 \mathrm{p}$.

Bunnell, D., 2008, Vertical sea caving: NSS News, v. 66, no. 10, p. 11-18. Bunnell, D., 2009, Return to Santa Cruz Island: NSS News, v. 67, no. 1, p. $12-19$.

Carew, J.L., and Mylroie, J.E., 1995a, Quaternary tectonic stability of the Bahamian Archipelago: Evidence from fossil reefs and flank margin caves: Quaternary Science Reviews, v. 14, p. 145-153.

Carew, J.L., and Mylroie, J.E., 1995b, A stratigraphic and depositional model for the Bahaman Islands, in Curran, H.A., and White, B., eds., Terrestrial and Shallow Marine Geology of the Bahamas and Bermuda, Geological Society of America Special Paper 300, p. 5-31.

Carew, J.L., and Mylroie, J.E., 1997, Geology of the Bahamas, in Vacher, H.L., and Quinn, T.M., eds., Geology and hydrogeology of carbonate islands, Developments in sedimentology, Amsterdam, Elsevier, v. 54, p. 91-139.

Dasher, G.R., 1994, On Station: A complete handbook for surveying and mapping caves, Huntsville, Ala, National Speleological Society, 242 p.

Florea, L.J., Mylroie, J.E., and Price, A., 2004, Sedimentation and porosity enhancement in a breached flank margin cave: Carbonates and Evaporites, v. 19, p. 75-85. 
Labourdette, R., Lascu, I., Mylroie, J., and Roth, M., 2007, Process-like modeling of flank margin caves: From genesis to burial evolution: Journal of Sedimentary Research, v. 77, p. 965-979.

Lace, M.J., 2008, Coastal cave development in Puerto Rico: Journal of Coastal Research, v. 24, no. 2, p. 508-518.

Moore, D.G., 1954, Origin and development of sea caves: National Speleological Society Bulletin, v. 16, p. 71-76.

Mylroie, J.E., 2007, Cave surveys, cave size, and flank margin caves: Compass and Tape, v. 17, no. 4, p. 8-16.

Mylroie, J.E., and Carew, J.L., 1990, The flank margin model for dissolution cave development in carbonate platforms: Earth Surface Processes and Landforms, v. 15, p. 413-424.

Mylroie, J.E., and Carew, J.L., 1991, Erosional notches in Bahamian carbonates: Bioerosion or groundwater dissolution?, in Bain, R.J., ed., Proceedings of the 5th Symposium on the Geology of the Bahamas, Port Charlotte, Fla, Bahamian Field Station, p. 185-191.

Mylroie, J.E., and Carew, J.L., 1995, Chapter 3, Karst development on carbonate islands, in Budd, D.A., Harris, P.M., and Saller, A., eds., Unconformities and porosity in carbonate strata, American Association of Petroleum Geologists Memoir 63, p. 55-76.

Mylroie, J.E., and Carew, J.L., 2008, Field guide to the geology and karst geomorphology of San Salvador Island, San Salvador, Bahamas, Gerace Research Centre, 88 p.

Mylroie, J.E., and Mylroie, J.R., 2007, Development of the carbonate island karst model: Journal of Cave and Karst Studies, v. 69, p. $59-75$.

Mylroie, J.E., and Mylroie, J.R., 2009, Caves of the Bahamas; Guidebook for excursion no. 82, $15^{\text {th }}$ International Congress of Speleology: Huntsville, Ala., National Speleological Society, 76 p.

Mylroie, J.E., Mylroie, J.R., Jenson, J.W., and MacCracken, R.S., 2008, Fresh-water lens anisotropy and flank margin cave development Fais Island, FSM, in Freile, D., and Park, L., eds., Proceedings of the $13^{\text {th }}$
Symposium on the geology of the Bahamas and Other carbonate regions, San Salvador, Bahamas, Gerace Research Centre, p. $135-139$.

Nardacci, M.L., 2002, A Guide to the geology and caves of the Acadian Coast, 2002 NSS Convention, Camden, Maine, National Speleological Society, $91 \mathrm{p}$.

Palmer, A.N., 1991, Origin and morphology of limestone caves: Geological Society of America Bulletin, v. 103, no. 1, p. 1-21, doi:10.1130/0016-7606(1991)103<0001:OAMOLC>2.3.CO;2.

Palmer, A.N., 2007, Cave geology, Dayton, Ohio, Cave Books, 454 p.

Roth, M.J., 2004, Inventory and geometric analysis of flank margin caves of the Bahamas [MSc. thesis], Mississippi State, Mississippi State University, 117 p. http://library.msstate.edu/etd/show.asp?etd=etd07062004-164930

Roth, M.J., Mylroie, J.E., Mylroie, J.R., Ersek, V., Ersek, C.C., and Carew, J.L., 2006, Flank margin cave inventory of the Bahamas, in Davis, R.L., and Gamble, D.W., eds., Proceedings of the $12^{\text {th }}$ Symposium on the Geology of the Bahamas and Other Carbonate Regions, San Salvador, Bahamas, Gerace Research Center, p. $153-161$.

Stafford, K.W., Mylroie, J.E., Taboroši, D., Jenson, J.W., and Mylroie, J.R., 2005, Karst development on Tinian, Commonwealth of the Northern Mariana Islands: Controls on dissolution in relation to the carbonate island karst model: Journal of Cave and Karst Studies, v. 67 , no. 1 , p. $14-27$.

Taboroši, D., Mylroie, J.E., and Kirakawa, K., 2006, Stalactites on tropical cliffs: Remnants of breached caves or subaerial tufa deposits?: Zeitschrift für Geomorphologie, v. 50, p. 117-139.

Waterstrat, W.J., 2007, Morphometric differentiation of flank margin caves and littoral, or sea caves [MSc. thesis], Mississippi State, Mississippi State University, 201 p. http://library.msstate.edu/etd/ show.asp?etd=etd-04052007-150907 